\title{
Oil Fields of Kentucky and Tennessee
}

\author{
By L. C. Glenn, ${ }^{*}$ Ph. D., Nashville, Tenn.
}

(New York Meeting, February, 1920)

IN THE preparation of this paper the writer has drawn freely upon the writings of Orton, Munn, Shaw, Mather, Miller, Hoeing, St. Clair, Jillson, and others, as well as upon his own personal knowledge of the fields of both states. It is to be regretted that certain data gathered by him and his assistants last fall are not available for publication.

\section{Oil in Tennessee}

A few wells drilled for brine for salt making in Tennessee between 1820 and 1840 obtained oil, but no definite search was made for oil until just after the close of the Civil War. Active drilling was then begun in Overton and counties southwest of it on the eastern half of the Highland Rim. A number of strikes were made at shallow depths in the basal part of the Mississippian but the wells were soon exhausted and abandoned. Drilling was revived, about 1892, when the Spurrier district in Pickett County was developed and was followed by the Riverton district in the same county in 1896. A pipe line was laid from the Wayne County, $\mathrm{Ky}_{y}$, fields and about $60,000 \mathrm{bbl}$. of oil were run before a very heavy slump in the production, a failure to find an extension of the field, and excessive local taxation caused the removal of the pipe line in 1906. There was then no production in Tennessee until the discovery, in 1915, of oil near Oneida, Scott Co., at about $950 \mathrm{ft} .(289 \mathrm{~m}$.) in fissures in the Newman or St. Louis limestone. This field, however, soon failed and was abandoned.

In 1916, oil was found at Glen Mary, Scott Co., in the Newman limestone at a depth of $1232 \mathrm{ft}$. $(375 \mathrm{~m}$.) A number of wells have since been drilled there, some of which were dry while others, close by, were producers. The largest one yielded, at first, about $340 \mathrm{bbl}$. per day and produced for several months, when it suddenly went dry. Several of the first wells began at 6 or 8 bbl. per day and are still maintaining that output. Production is from a fissured part of the limestone and varies greatly in accordance with the size and extent of the ramification of the

* Consulting Oil Geologist and Professor of Geology, Vanderbilt University. 
fissures. In some areas, the limestone has no fissured zone and wells go through it without obtaining even a show of oil. Fissuring, when present is not always at the same horizon in the limestone and failure to obtain a well in one location does not necessarily mean that the next location may not be a successful producer. The production at present is probably not over $1000 \mathrm{bbl}$. a month. The oil is shipped to Somerset, Ky., in tank cars and there delivered to the Cumberland pipe line.

The limestone in which the oil occurs has, so far as has been ascertained, a monoclinal structure and rises gently to the west. There is only a little gas with the oil and little or no salt water is encountered. No production curves can be given since the wells vary greatly. Some decline rapidly and fail in a few months while others show scarcely any decline after several years and bid fair to have a long life as pumpers of about 6 to 8 bbl. per day. The gravity is from $36^{\circ}$ to $38^{\circ}$ Baumé.

There is now considerable activity in both leasing and drilling, especially in the western half of the Highland Rim, west and northwest of Nashville, although the eastern and southern parts of this Rim are also receiving some attention. The surface of the Highland Rim is almost everywhere of Mississippian age and is underlaid, at a maximum depth of not more than a few hundred feet, by the Chattanooga black shale. Oil shows are often found just above or just below this shale. Much of the activity has been stimulated by the finding of oil in Allen County, $\mathrm{Ky}$, under geological conditions very similar to those that obtain in the adjacent Highland Rim section of Tennessee.

There has been occasional deep drilling in Tennessee for a number of years, especially in the Central Basin, where the surface rocks are of Ordovician age, in the hope of obtaining a deep pay usually spoken of as the Trenton. All such attempts in this part of the state have so far failed. There have been a few slight shows and a little gas has been found, but no good sand has been encountered. The only Ordovician production from Tennessee has been that in Pickett County.

A half dozen holes or more have been bored in the last 10 years in the western part about Memphis, and to the north of it, near the axis of the great trough in which the Gulf embayment deposits have been laid down. These wells usually range from 2000 to $3000 \mathrm{ft}$. (609 to $914 \mathrm{~m}$.) in depth and several of them reported shows of oil or gas in the lower part of the section. Very recently, activity in this part of the state has been revived and preparations for further deep testing of the embayment deposits in the vicinity of Reelfoot Lake in the northwestern corner of the state are now being made.

The history of attempts at oil production in Tennessee give meager data on which to base any predictions of a large future oil production. No well-defined oil sands of any considerable extent are known, although large areas of the Newman limestone exist beneath the Cumberland 
plateau, under conditions very similar to those at Glen Mary, and remain untested by the drill. Should portions of these be notably fissured, they might furnish an oil field of much importance. It is entirely possible that oil may be found in various parts of the Highland Rim, either in the Waverly rocks close above the Chattanooga black shale or in Onondagan or Silurian limestones close beneath it. Such rocks appear to the writer as the most promising for further drilling. Oil is much less probable in the Ordovician rocks, since sand and other conditions do not usually seem favorable there.

The surface of the Cumberland plateau consists of Pennsylvanian sandstones and shales of Pottsville age that attain a maximum thickness of $1000 \mathrm{ft}$. (304 m.) or slightly more, beneath the general plateau level. So far, there is no evidence, either from occasional wells that have gone through them or from their character as they outcrop on either side of the plateau, that the Pottsville rocks contain oil in Tennessee. Should it occur, it would most probably be found in that portion nearest the Kentucky line, as oil is obtained from several Pottsville horizons in Knox County, Ky., not far to the northeast.

The Gulf embayment sands and clays of western Tennessee attain a thickness in excess of $2500 \mathrm{ft}$. $(762 \mathrm{~m}$.), and may be $3500 \mathrm{ft}$. (1066 m.) thick along the axis of the trough, before the Paleozoic floor on which they rest has been reached. The lower part of these embayment rocks are of Cretaceous age and are the equivalents of the rocks that yield oil and gas in northwestern Louisiana. It is possible that they may contain oil in western Tennessee, although structural relations are so obscured by a blanket of surficial sands and by the general flatness of the region that drilling there must be largely a matter of chance and success mainly the result of luck. It is further possible that some part of the old Paleozoic floor beneath the embayment deposits may contain oil, although there is no means of determining either the lithologic character or the structure of the older rocks from surface inspection. Where they go under the embayment deposits near the Tennessee river, they vary in age from Silurian to Mississippian. Their surface is usually regarded as a beveled erosional one, so that it is probable that the floor of the embayment may, in the deeper parts, be composed of Ordovician rocks.

\section{OIL IN KeNTUCKY}

Oil is produced in Kentucky in a large number of separate areas, most of them small. They are widely scattered through the east central, eastern, southeastern, southern, and southwestern parts of the state. Only one of these, situated in Estill and Lee Counties and generally known as the Irvine field, is of very great size. This includes a recent 
extension to the southeast known as the Big Sinking Creek field. The most northeasterly are the Fallsburg and Busseyville pools in Lawrence County, and the most castern is the Beaver Creek field in Floyd County. Closely connected with the Irvine-Big Sinking pool in the central eastern part of the state are the Station Camp, Lost Creek, Campton, Stillwater, and Cannel City pools; and a short distance to the northeast is the Ragland pool. In the southeastern part of the state is the Knox County area north of Barbourville, and a number of small pools in Wayne County. In Lincoln County, there is a small area northeast of Waynesburg. In the southwest, there are the Barren County fields, a small area in the eastern edge of Warren County and a number of small detached areas in Allon County, the most important of which are grouped about Scottsville. Elsewhere, there are a few isolated wells or very small groups of wells not important enough to be given specific mention.

The first oil in Kentucky was discovered, by accident, in 1819 while drilling for a salt well near the south fork of Cumberland River in what is now McCreary County. The oil came probably from the Mississippian. The next find was made, in 1829, on Renox Creek near Burksville, Cumberland County, and was from Ordovician rocks. This well flowed for many miles down Cumberland River, caught fire, and burned for some time. Later its products were used for medicinal and other purposes, until about 1860 .

Following the discovery of oil in Pennsylvania, discoveries were made in Wayne and other counties along the Cumberland river, from 1861 to 1866. Most of the oil obtained was shipped by bar-w down the Cumberland to Nashville, although a part was refined locally. Just after the war, there was renewed interest in the search for oil and additional discoveries were made, especially in Allen and Barren Counties, where oil was found close beneath the Devonian black shale. Interest waned between 1870 and 1880 , but was revived during the last two decades of the century, when additional discoveries were made in Barren County west of Glasgow, in Lawrence County on Big Blaine creek, and in Floyd and Knott Counties on the right fork of Beaver creek; while in Wayne County renewed activity led to important discoveries in a number of localities. The most important production in Wayne was found in the Beaver sand in the lower part of the Waverly, but some oil was also obtained below the black shale. During the two decades from 1880 to 1900 , the average production for the entire state was not over $5000 \mathrm{bbl}$. per year; the maximum production was in 1899 when $18,280 \mathrm{bbl}$. were produced.

The modern period in the development of oil in Kentucky may be said to date from the discovery of the Ragland field in Bath County, in 1900. In this field, oil was found in the Onondaga limestone at a depth of 300 to $380 \mathrm{ft}$. (91 to $115 \mathrm{~m}$.) beneath the Licking River valley. By 
1904, the field was practically drilled up and production since then has gradually declined until it is very small. The Sunnybrook pool, Wayne Co., was discovered in 1901. Oil was obtained from the Trenton, which came to be known locally as the Sunnybrook sand. There was a considerable yield, but it was short lived and within a few years the field had been abandoned. Many further attempts have since been made to obtain oil from the Trenton, or Sunnybrook, both in Kentucky and in Tennessee, but so far they have been without success. Following the Sunnybrook development, much drilling was done elsewhere in Wayne and adjoining counties, and a number of small pools were developed, chiefly in the Beaver sand.

In 1901, oil was found in the northern part of Knox County on Little Richland Creek, near Barbourville. The oil came from three sands in the Pottsville, named in descending order the Wages, Jones, and Epperson. The wells were small producers and were practically all abandoned in a few years. Recently there has been renewed activity in the Barbourville region, but nothing noteworthy has developed.

In 1903, the Campton pool was discovered and by 1909 had been drilled up. Oil was found in the Onondaga limestone. Many of the wells have since been abandoned, but others in the field are still pumping $1 / 2$ bbl. or more per day. Shortly after this, wells were gotten at Stillwater on the eastward continuation of the Campton structure. They were very similar to the Campton wells and have had a similar history. The same structure yielded oil at Cannel City in 1912, and by 1913 a production of $12,000 \mathrm{bbl}$. per month had been attained. This rapidly declined, however, and the production today is merely nominal.

For many years oil has been known near Irvine, having been originally found in borings made for salt wells. Soon after the discovery of oil at Campton some shallow wells were bored at Ravenna, near Irvine, on the westward continuation of the structure on which the Campton wells were located. This structure is now generally known as the Irvine structure. The wells were very shallow, but yielded considerable oil for a number of years, until their decline led to the removal of the pipe line that had been laid in the early years of their development, and they were entirely abandoned. In 1915, a well drilled $3 \mathrm{mi}$. northeast of Irvine started the development of the present Irvine fields and ushered in the present period of intense activity of oil development in Kentucky. The producing sand is the Onondaga limestone, just beneath the black shale, and is generally known as the Irvine sand. The field was rapidly extended eastward and by 1917 had reached the Pilot section near Torrent, making the field about $12 \mathrm{mi}$. long and from 1 to $2 \mathrm{mi}$. wide. In 1918, there developed what might be called a southeastward extension of the Irvine field along Big Sinking Creek. Development in this new area 
was rapid and by the early part of 1919 its southern limits had been reached a mile or two northwest of Beattyville.

On Station Camp creek, some $8 \mathrm{mi}$. south of Irvine, a small pool was found in 1916, at less than $100 \mathrm{ft}$. ( $30 \mathrm{~m}$.) beneath the valley floor. It was drilled very closely and was soon practically exhausted. In similar fashion another small, shallow pool was discovered and developed on Ross Creek. Decline has set in there also but exhaustion has not yet been reached. About these two are grouped several still smaller productive areas of like character but of still more recent development.

Meantime, in 1903, oil was discovered at Busseyville and Fallsburg, Lawrence Co., in the Berea sandstone about 1400 to $1600 \mathrm{ft}$. (426 to 487 $\mathrm{m}$.$) in depth. The wells are small but maintain their production for$ years with but slight decline.

Although oil was produced in Allen County about the close of the Civil War, it was not until about 1915 that the modern period of production there was ushered in by the drilling near Scottsville of a number of small wells 200 to $300 \mathrm{ft}$. deep. The oil came from close beneath the black shale from either Onondaga or Niagara limestone. Development has been checked until very recently by inadequate transportation facilities. Most of the development is to the south of Scottsville, but there are several small areas in the northwestern part of the county and recently an important well or two have been drilled just across the line in the eastern edge of Warren County. Wildcat wells are being drilled in numerous places in nearly all sections of the state except the central and northern part, where the surface rocks are of Ordovician age, and in the extreme western part within the area of the Mississippi embayment deposits.

\section{Geology of Kentucky On Fiends}

A list of geological horizons designed to include all sands that have at any time furnished oil in Kentucky would be quite lengthy. A list confined to horizons producing oil today in commercial quantities follows:

\begin{tabular}{|c|c|c|c|c|c|}
\hline \multirow{5}{*}{$\begin{array}{c}\text { Prrion } \\
\text { Carboniferous }\end{array}$} & \multicolumn{5}{|c|}{ Principal Productive OIL Sands in Kentucky } \\
\hline & \multirow{4}{*}{$\begin{array}{l}\text { Epocr } \\
\text { Pottsville }\end{array}$} & \multicolumn{4}{|c|}{ OIL AND GaB HoRtzong } \\
\hline & & Beaver & & & \\
\hline & & Horton & of Floyd and & Jones & of Knox Cos. \\
\hline & & Salt & & & \\
\hline Mississippian & Waverly & \multirow{2}{*}{\multicolumn{2}{|c|}{ Berea of Lawrence Co. }} & Stray and & of Wayne \\
\hline & & & & $\begin{array}{l}\text { Beaver } \\
\text { Creek }\end{array}$ & and Mc- \\
\hline Devonian & Onondaga & \multirow{2}{*}{\multicolumn{4}{|c|}{$\begin{array}{l}\text { Of Olympia, Ragland, Cannel City, Stillwater, } \\
\text { Campton, Irvine, Big Sinking Creek, Ross Creek, } \\
\text { Station Camp Creek, Lanhart, Buck Creek, } \\
\text { Miller's Creek, Heidelberg, Barren Co., Warren } \\
\text { Co., Allen Co., Ohio Co. }\end{array}$}} \\
\hline & (Corniferous) & & & & \\
\hline
\end{tabular}


In Floyd and Knott Counties, four sands occur in the lower part of the Pottsville; these, in descending order, are: the Beaver, Horton, Pike, and Salt sands. They are all sandstones and each varies in thickness from less than $50 \mathrm{ft}$. $(15 \mathrm{~m}$.) to more than $300 \mathrm{ft} .(91 \mathrm{~m}$.$) . The interval$ between them also varies from a few feet to over $100 \mathrm{ft}$., making it practically certain that the sands split and reunite in such irregular ways that correlation of them is uncertain. In Knox County, the Wages, Jones, and Epperson sands of the lower Pottsville are also sandstones and vary considerably both in thickness and in interval. Their correlation from well to well is doubtful at times and no correlation has so far been possible with the Floyd County sands. The Berea sand of Lawrence County is a medium grained sandstone that usually runs from 50 to $100 \mathrm{ft}$. in thickness and lies at the base of the Waverly.

In Wayne and McCreary Counties, the principal oil-bearing horizon is a cherty, geodal limestone known as the Beaver Creek sand. It lies just above the Chattanooga black shale and forms the basal member of the Waverly. It varies greatly in thickness, texture, and porosity and the production of the wells in it varies accordingly. In some cases, a similar oil-bearing limestone is found near the top of the Waverly in these counties and is known as the "Stray sand." It is usually from 10 to 30 ft. ( 3 to $9 \mathrm{~m}$.) thick.

The Onondaga, or Corniferous, limestone is by far the most important oil-bearing horizon in the state. It lies close beneath the Genesee or Chattanooga black shale. It is a soft brown, porous to cavernous, magnesian limestone which, in the Irvine fields, thickens to the east from 20 or $30 \mathrm{ft}$. ( 6 to $9 \mathrm{~m}$.) about Irvine to from 70 to $95 \mathrm{ft}$. on Big Sinking Creek. The pay exists in from one to several streaks that have no regular distribution or position. Between the pay portions, the limestone is hard and close grained. In Allen County, the pay may extend down into fissured or porous limestone of Silurian age.

Genuine sandstones occur in Kentucky as oil-producing sands only in the Pottsville and Berea, and their aggregate production amounts to less than 2 per cent. of the total production of the state; 98 per cent. of the production comes from limestones. In a sandstone, the distribution of porosity is usually more uniform than in a limestone, where the porous, fissured, or cavernous condition is apt to be irregular in occurrence. This difference in the nature of the two rocks explains the marked differences in the amount of pay, in the yield of nearby wells, and the freakish occurrence of dry holes in the midst of production where the sand is a limestone.

If one takes the percentage of the present production from the several sands given in the preceding table, it will become evident that the producing horizons in the state vary greatly in their relative importance and that the one sand of prime importance is the Onondaga, or possibly, the 
Onondaga linked with the Niagara for Ohio and parts of Barren, Warren, and Allen Counties. The aggregate production, however, from these counties is so small, relatively, that the importance of the Onondaga as the premier oil horizon of the state is not materially diminished.

\section{Approximate Yield of Oil by Geological Horizons in Kentucky}

\begin{tabular}{|c|c|}
\hline Pottsville of Knox, Floyd, and Knott Counties. & $\begin{array}{l}\text { Per Cent. } \\
1 / 2 \text { to } 1\end{array}$ \\
\hline Berea of Lawrence County ..................... & 1 \\
\hline Stray and Beaver Creek of Wayne and McCreary Counties.. & 2 \\
\hline Onondaga, of Allen, Barren, Warren and Ohio Counties (?). . & 4 \\
\hline Onondaga, of Irvine-Big Sinking and other nearby areas.... & 92 to $921 / 2$ \\
\hline
\end{tabular}

\section{Structure in Relation to Oil Occurrence}

All of the oil fields in the central eastern part of the state are on the eastern or southeastern flank of the Cincinnati anticline. The rocks in which they occur rise gently to the west out of the great Appalachian trough, whose axis lies along the extreme eastern border of the state. Oil has migrated up the slope of these rocks to the westward until arrested by an anticline with a northeast-south west axis, whose north western limb has usually been faulted in simple or compound fashion. The most important part of the great major anticline of this region extends from near Irvine eastward to Paint Creek, though the extreme limits are more remote at either end. Subordinate and somewhat parallel anticlines occur in the Ragland and in other minor fields near the Irvine field. There has apparently been some cross folding also that has corrugated the slope up which the oil has migrated and concentrated it in certain more favorable localities. The Irvine field, however, presents certain anomalies worthy of mention in this connection. The axis of the anticline pitches to the northeast at a rate more than sufficient to cause the migration of oil westward along it and without, so far as the writer knows, any cross folding sufficiently strong to check such movement; yet oil is found along this axis at intervals from Irvine eastward to Cannel City with only a few dry areas between the separate pools. Again, the eastern end of the Irvine field proper has a broad southeastward tongue that extends a number of miles down the dip in the Big Sinking Creek area. It seems that this oil should have migrated farther up the slope to the northwest and have been found nearer the axis, since it has salt water below it to push it onward.

In the Lawrence field, the Berea sand seems to have an anticlinal structure, which combined, perhaps, with difference in porosity may explain the occurrence of the oil there.

In the Pottsville sands, in Floyd and Knott Counties, oil moving up the dip to the westward has been arrested either by slight terraces or by vos. Lxr. -9 . 
encountering tight places in the sand. There is no anticlinal structure. Similar structural conditions prevail, so far as the writer knows, in the Knox County wells north of Barbourville.

In the Wayne County field, the oil favors, according to Munn, the sides and bottom of synclinal troughs that slope gently eastward.

In Allen County, recently published work by Shaw and Mather show a number of small anticlines and domes with an area of 2 to 3 sq. mi. each, superimposed upon a prevalent northwestward dip of perhaps $40 \mathrm{ft}$. $(12 \mathrm{~m}$.) to the mile. These have a closure of 25 to $30 \mathrm{ft}$. (7 to $9 \mathrm{~m}$.) or less, and their location, from a study of the surface, is of ten difficult or impossible because of lack of exposures. These same features and lack of exposures characterize much of Barren County and the eastern part of Warren County. In the western part of Warren County, exposures are better and pronounced doming and terracing occurs. These structures have yielded considerable shows of oil near Gasper River.

Water usually follows the oil in the Onondaga rather closely. It soon begins showing in the wells in the lowest part of the structure and, as time passes, invades the field farther and farther up the dip. Water has thus encroached upon part of the Irvine field and has appeared in the Big Sinking field. Concerted efforts should be taken by operators there to combat this invasion.

\section{TechNology}

Drilling was formerly by standard rig; and in deep tests in wildcat territory this method is still used. Most of the known production can, however, more easily be reached by drilling machines. Wells in the Allen fields 250 to $300 \mathrm{ft}$. (76 to $91 \mathrm{~m}$.) deep cost about $\$ 1000$ complete. In the Big Sinking field, wells 800 to $900 \mathrm{ft}$. deep cost about $\$ 3500$; while those 1000 to $1200 \mathrm{ft}$. deep cost from $\$ 5000$ to $\$ 6000$. Prices for drilling tend to rise in harmony with all other prices at present.

The size of Kentucky wells varies greatly both for the various pools and for adjacent locations in the same pool. This is true especially if the sand is a limestone. The rate of decrease also varies greatly. Reliable determinations of this rate are made difficult by the development of the more important pools having been so recent that their records of production extend over only a very few years. This difficulty is further increased by the fact that pipe-line facilities have until very recently been entirely inadequate to take care of the production. In the Allen County fields, transportation conditions have been especially bad, and while partly remedied are not yet entirely satisfactory.

In Lawrence County, wells in the Berea sandstone come in at from 4 to 8 or $10 \mathrm{bbl}$. and show only a very slow decline over a long period of years.

In Floyd County, where the oil is also derived from sandstone, the 
initial production is likewise small but is well maintained. Some of the wells drilled 10 to 20 years ago show only slight decline.

In Wayne County, where production is from a limestone, the initial yield varies greatly, though some of the largest wells produced from 100 to 500 bbl. daily for a short time. The average initial production, however, is well below $100 \mathrm{bbl}$. These wells soon settle to $20 \mathrm{bbl}$. or less per day and then usually show only a slight further decline. In some cases there has been practically no decline in 15 years; in other cases, the yield in that time has decreased to a barrel or two or even less. Many of these old wells have been overhauled recently and put on a vacuum with a gratifying increase in yield.

In the Irvine district, initial production also varies greatly. The average, given by Shaw, for successful wells drilled between October, 1915 , and February, 1917, is about $39 \mathrm{bbl}$., and the producing wells were 89 per cent. of the total number drilled. Few exceeded $100 \mathrm{bbl}$. each. In Big Sinking Creek a number of wells have had an initial production of several hundred barrels and a few have probably yielded $1000 \mathrm{bbl}$. per day. The decline in the Irvine field by the end of the first year has been to about 10 per cent. of the initial yield, although some wells have held up considerably better. This rate of decline has been due to the porosity of the sand and the close spacing of the wells in many cases. In parts of the Station Camp and Ross Creek pools, wells have been spaced one to an acre or less. The well spacing in the Big Sinking field has also been entirely too close on certain properties and has been attended with a rapid decrease in production.

In the Allen County region, about 75 per cent. of the wells drilled have been successful. Initial production for the larger wells has varied from 25 to $100 \mathrm{bbl}$. per day with a few exceptional wells yielding 200 to $300 \mathrm{bbl}$. The gas pressure behind these largest wells, however, is quickly relieved and in a few days they decrease greatly. By the end of the first month, the larger ones yield from one-fourth to one-third of their initial production, while the smaller ones hold up somewhat better. These smaller wells come in at from 5 to $20 \mathrm{bbl}$. per day.

In Barren County, a well recently abandoned because of decreased flow and the eating away of the casing produced oil for over 40 years and during that period showed a remarkably low decline curve. It was probably next to the oldest well in the country at the time of abandonment. ${ }^{1}$

Future production curves and tables have been published by the Internal Revenue Department for Floyd County, Beaver Creek in Wayne County, Ragland and Irvine, in its "Manual for the Oil and Gas Industry."

The oil varies considerably in character. Most of it is dark green by reflected light, but dark brown when seen by transmitted light in thin films. A little amber oil has been reported from Barren, and occasion-

${ }^{1}$ A well in Wirt County, W. Va., drilled in 1860 is still producing. 
ally elsewhere, but the quantity of such oil is negligible. In gravity, it ranges from $26^{\circ}$ to $45^{\circ} \mathrm{Be}$. In the Floyd field, the average is about $40^{\circ}$. In Wayne county, it varies from $36^{\circ}$ to $43^{\circ}$. In the Irvine field, the average range is $30^{\circ}$ to $36^{\circ}$. In the Ragland field, the average is $26^{\circ}$ or $27^{\circ}$. Allen county averages from $35^{\circ}$ to $38^{\circ}$; and Barren about $40^{\circ}$ to $42^{\circ}$. The gasoline content is usually high.

In the Lawrence, Floyd, Knox, and Wayne County fields, no abnormal values have attached to lands; but in the Irvine district values, especially in Big Sinking field, have rapidly risen until prices of $\$ 2000$ to $\$ 5000$ per acre have been reached with extra royalties at times. In Allen County and near the Moulder well in the eastern part of Warren County, high prices have also been given recently for acreage. Wildcat acreage has, in many places, been held at high figures when compared with equal grade acreage in many other states and much development in certain sections has been retarded by these prices.

The great bulk of the oil in Kentucky is transported by the Cumberland pipe line, which has lines serving practically all of the eastern and southeastern parts of the state. It does not, however, reach the fields of Allen and adjacent counties. Until recently its capacity was inadequate to care for the possible full production. A little oil in the eastern fields is handled by short private lines, by barges, or by tank cars. In Allen County, several small pipe lines gather the oil and deliver it to loading racks at Scottsville and Bowling Green for shipment to Nashville, Louisville or elsewhere.

\section{Future Possibilities}

There is a good chance for finding a number of small pools in the Pottsville and the Berea in the eastern part of the state on small structures or under favorable conditions of the sand. Such pools may be expected to have the general character of those in Lawrence, Floyd, and Knox Counties; starting with a small production, but sustaining it well for a long period.

The Onondaga oil is seemingly confined to a narrow belt near the outcrop of these rocks in the central eastern part of the state, which has already been pretty thoroughly tested and developed. The writer looks for no large new pool from that horizon there. Where the Onondaga crosses the saddle between the Cincinnati and Nashville domes in the Barren, Warren, and Allen areas, there doubtless remain a number of new finds; but the difficulty in determining the structure because of the prevalent surface soil covering will make their discovery either a matter of slow detailed work or of chance.

There should be chances of finding oil on the sides of the basin in which the west Kentucky coal field lies where the Mississippian, Devonian, and perhaps Silurian rocks rise from that basin to the east and southeast, 
wherever domes, terraces, or other favorable structures can be located. The chance on the south side of this basin is less favorable because of the extensive faulting there.

Within the West Kentucky coal field, the writer believes the only favorable chance of finding oil is along the Gold Hill-Rough Creek disturbance and conditions there are complicated because of the severity of the folding and faulting. In the Gulf embayment deposits of West Kentucky, there are no known structures; and it is too soon to make prediction worth anything until the results of the testing soon to be done in the nearby Reelfoot Lake district in Tennessee are known. Much light should then be thrown on the oil possibilities of these embayment rocks in Kentucky.

Little or no oil need be expected in the Ordovician or in any older rocks and drilling in any part of the central blue grass limestone region of the state is practically money wasted.

\section{DISCUSSION}

Mortimer A. Sears, Huntington, W. Va. (written discussion).-In dealing with the future possibilities for oil and gas in Kentucky, I regret that Doctor Glenn has failed to mention the Paint Creek Dome, which lies in parts of four counties, viz., Johnson, Magoffin, Morgan, and Lawrence. This immense structural uplift has possibilities second to none in the state. It lies along the line of structural uplift known to extend from the Irvine field through Kentucky, and into West Virginia, where it is known as the Warfield anticline.

In an article that I wrote for the Oil and Gas Journal (May 21, 1917), I stated the geologic facts in connection with this field, which at that time was strictly a wildcat proposition. It is true that wells have been put down at various times since about 1860 , but such operations were spasmodic and haphazard. So far as I know there had been no geologic report relating to oil and gas upon this area at the time I made my examination (February, 1917)-except in the form of a communication from Prof. J. P. Leslie to the American Philosophical Society in 1865. After February, 1917, development dragged along slowly until about a year ago, when more energetic measures were inaugurated, with the result that about 20,000,000 cu. $\mathrm{ft}$. of gas per day has been developed and several oil wells having capacities of from 3 to $50 \mathrm{bbl}$. per day have been brought in.

Commercial quantities of gas occur in the Weir sand at a depth from the surface of about $850 \mathrm{ft}$. $(259 \mathrm{~m}$.); it varies in thickness from 20 to 40 feet. Part of the product is sold to the Central Kentucky Natural Gas Co., and part to the Louisville Gas and Electric Co. These two companies have main gas lines extending through the field about $5 \mathrm{mi}$. from 
the particular area in which gas has been found. Lateral lines have been laid and compressor plants are in operation.

The largest oil wells in the field find their product in the Weir sand also, although commercial quantities of oil have been found in the Berea. The Weir sand appears to be a "genuine sandstone" and seems to prove an exception to Doctor Glenn's statement that genuine sandstones occur in Kentucky as oil-producing sands only in the Pottsville and Berea. It may correspond to one of the oil sands of Wayne and McCreary Counties, but it certainly cannot be called a "geodal limestone."

The Keener, also, has produced small amounts of oil. It is from this sand that a well recently brought in produced an oil of $51^{\circ}$ Bé. gravity. The weir oil runs about $38^{\circ} \mathrm{Bé}$. The Cumberland Pipe Line Co. expects soon to lay a line into the field.

The last well brought in showed the Weir sand to be over $60 \mathrm{ft}$. $(18 \mathrm{~m}$.) thick with a 16 -in. $(40-\mathrm{cm}$.) break. Thus far, wells drilled to the Onondaga (Coniferous) have proved disappointing and no production has been found in the Clinton. Comparatively few wells are drilled below the Weir so that it is yet too early to condemn the lower formations.

Leases are constantly changing hands. Very little acreage remains in the hands of the land owner. Whenever a well is brought in, leases sold on adjacent property bring from $\$ 100$ to $\$ 150$ per acre. With the opening of spring there is no question but that this area will be the scene of the greatest activity in the state of Kentucky.

Wilbur A. N. Nelson, ${ }^{*}$ Nashville, Tenn. (written discussion).Certain pertinent facts in regard to the oil produced in Tennessee in the past and to the extension of the different formations of Allen County, Kentucky, into Middle Tennessee are not given in this paper.

The very heavy slump in production that occurred in the old Riverton Spurrier district of Pickett, Tenn., was due to fresh-water troubles. A recent study of the water troubles of this field brings out these facts: Under the Chattanooga "black" shale occurs a practically uniform bed of Ordovician limestone, bedded or creviced so as to permit a connection between the different gas shows in the upper part of the limestone immediately under the black shale and the oil horizons in the base of the limestone, some 165 to $270 \mathrm{ft}$. below the black shale. In the old wells, the casing was set below the gas shows and just above the oil horizon. That the release of the gas pressure permitted the fresh water to flow down through the limestone joints, bedding planes, or fractures to the oil horizon and thus drown out the well, seems to have been proved by Mr. J. H. Compton, of Riverton. Several years ago he reset the casing in one well above the first gas show and, after plugging the other wells,

* State Geologist, Tennessee Geological Survey. 
he gas horizon, started pumping. After several weeks, the well commenced to produce oil.

A structural report recently made on this area by the Tennessee ieological Survey, in coöperation with the U. S. Geological Survey, shows that the best old producing wells were located on the crest and north flank of a long narrow anticline extending in a direction of approximately north $60^{\circ}$ east and that the oil probably occurs in pools of small extent with a radius of about $1 / 2 \mathrm{mi}$. Several similar anticlines were mapped in this district, which are yet untested. The Cumberland Pipe Line Co. laid a 2-in. line into this field in 1902, which was removed in 1905 , due to a decline in oil production but primarily to the levying of a $\$ 10,000$ annual tax on the line by Pickett County. During this time $58,776 \mathrm{bbl}$. of oil were piped from this field, of which over $36,000 \mathrm{bbl}$. came from one well, known as the Bobs Bar well, which shortly went to water.

In Sumner County, Tenn., and in adjoining counties to the west and southwest on the Highland Rim, there is at present much drilling going on, but the majority of these wells have been drilled without paying any attention to structure. This was recently shown in Sumner County, which joins Allen County, Ky., on the south. A detailed structural map of part of this county made by the Tennessee Geological Survey, in coöperation with the U. S. Geological Survey, shows that of over 30 holes drilled only two were located on favorable structure. But on that particular dome, one could have little hope of finding oil, as the oil horizon had been cut through on the south flank of the dome. The structurally favorable places are still untested.

In Allen County, $\mathrm{Ky}$, around Scottsville, the oil is found at three horizons below the Chattanooga black shale. These three sands are not always present at one place; and when present, as a rule only one is producing. The upper, sometimes the two upper, sands are considered of Devonian age and probably correlate, in Tennessee, with the Pegram limestone. The lower sand, which produces most of the oil to the south of Scottsville, is thought to be of Silurian age and to be Louisville limestone, as this formation outcrops in Sumner County, Tenn., just south of Allen County, Ky., at the base of the Chattanooga black shale, the Corniferous beds of Devonian age being absent.

The location of the old shore line of the Pegram limestone, as it is known in Tennessee, and of the Corniferous limestone, as it is known in Kentucky, is important. Exposures of this limestone are not known south of Petroleum, Allen County, Ky. No outcrops are known in Sumner County, Tenn., but it appears again $12 \mathrm{mi} .(19 \mathrm{~km}$.) west of Nashville, at Newsom Station, where it has a thickness of $3 \mathrm{ft} .(0.9 \mathrm{~m}$.$) ;$ a few miles farther west, at Pegram, in Cheatham County, it has a thickness of $12 \mathrm{ft}$. From these exposures it would appear that this shore 
line would extend from Newsom Station northeastward through' ham and Robertson Counties, Tenn., probably passing in the vii of Springfield, and crossing the state line in the proximity of the nor. east corner of Robertson County, near Mitchellville. All territory as far west of this area as the Tennessee River is underlain by Devonian limestones. A well was brought in, in January, 1920, in Simpson County, Ky., about $3 \mathrm{mi}$. from the northeast corner of Robertson County, Tenn. in a very peculiar sandy limestone $61 \mathrm{ft}$. below the Cbattanooga black shale. The sand was penetrated to a depth of $7 \mathrm{ft}$. and may be a phase of the Harriman chert of Oriskany age, which outcrops about $50 \mathrm{mi}$, to the southwest near Cumberland City, Stewart County, Tenn.

The shore line of the other supposedly oil-bearing limestone, the Louisville limestone of Silurian age, is of interest because of the effect it would have on possible oil territory in the counties on the western Highland Rim of Tennessee. In Sumner County south of Westmoreland, it is $20 \mathrm{ft}$. thick, while about $25 \mathrm{mi}$. to the southwest near Ridgetop, in Robertson County, it only shows a thickness of $10 \mathrm{ft}$. Farther to the southwest, in southern Cheatham County around Pegram, it is very thin, having a $15 \mathrm{ft}$. exposure. On the western edge of the Highland Rim along the Tennessee River, this formation changes to a shaly phase, known as the Lobelville, which varies in thickness from 10 to $75 \mathrm{ft}$. These facts would indicate that the extent of the limestone phase of the Louisville formation would lie just to the southeast of the present edge of the Highland Rim on the Middle Basin of Tennessee, as far south as Pegram, and that at this point the line would turn to the northwest, swinging back into Kentucky. The extreme thinness of the formation, except in the northern part of Sumner County and probably in the northern part of Robertson County, would indicate that only in these two areas would it be thick enough to act as a commercial oil reservoir. The long narrow embayments in which this and the overlying formations were laid down make it probable that there are areas in the northern Highland Rim counties lying outside of these old embayment areas in which these formations were never deposited. In the more southern counties on the Highland Rim west of Nashville, overlapping formations come in between the Louisville limestone and the Chattanooga black shale, which would keep this formation from containing oil if such oil is derived from the Chattanooga black shale. That this formation is probably absent in the southwestern part of Robertson County is indicated by the fact that a recent well on Sulphur Fork, 6 mi. southwest of Cedar Hill, which went to a depth of $1015 \mathrm{ft}$. and passed through the Chattanooga black shale at $615 \mathrm{ft}$., encountered no water, oil, or gas below the Chattanooga. This hole probably passed through the rocks of Trenton age at $950 \mathrm{ft}$. The presence of blue phosphate sand in the limestone above this level is taken as evidence of the presence of the Hermitage formation of Trenton age at this depth. 
above ti,tern Tennessee, two deep tests are being drilled, one in Lake again - at Proctor City on the west side of Reelfoot Lake and the other vion County near Walnut Log on the northeast side of Reelfoot Lake. rum numerous exposures of the formations just under the loess bluffs 1ortheast of Reelfoot Lake, it is thought that there is a marked antidinal area just to the northeast of Walnut Log and extending over the Tennessee state line into Kentucky. The oil and gas rights on Reelfoot Lake, which belongs to the state of Tennessee, have been leased by the Governor to the men who are drilling near Walnut Log. This hole is on land joining the state property. Among other things the state requires that the well be drilled to a depth of $3000 \mathrm{ft}$. The Paleozoic floor of the gulf embayment should be reached inside of that distance, while the formations producing oil in the northwest corner of Louisiana should be reached at about $2200 \mathrm{ft}$.

In Allen County, Ky., detailed structural work done to the south of Scottsville shows that in the area thus mapped the best production comes from the northwest or west side of small structural domes, with closures of about $20 \mathrm{ft}$., but where the dome has a very steep dip on the north or northwest side, with gentle dips to the south, the production is obtained on the south and southwest sides. Such production is always less than the production from the northwest sides of Allen County domes. In small wells that are shot, the production often drops off four-fifths after the first two or three days. In several cases, wells that have come in producing salt water change to oil after about two weeks pumping, and make average producers. No fresh water is encountered in the Allen County wells below the Chattanooga black shale. The average productiv. on this section is probably not more than $5 \mathrm{bbl}$. per pumping well.

Stuart St. ClaIR, Bowling Green, Ky. (written discussion).Doctor Glenn's paper is interesting as an historical résumé of the oil development in these states, the former of which has come into prominence during the past few years, producing, in 1919 , approximately $8,000,000$ bbl. of high-grade oil.

The writer had hoped that Doctor Glenn would give more detailed data on the accumulation of oil in the Onondaga limestone, as that formation furnishes about 96 per cent. of the oil production of Kentucky. If he had, in his discussion of the eastern part of the state, he would have noticed that his statement that oil has migrated westward up the slope of the rocks which rise from the great Appalachian trough until arrested by an anticline with a northeast-southeast axis, would need some modification or further explanation. Between the Appalachian trough and the Irvine District, the latter comprising the oil fields of Lee, Estill, Powell, and Wolfe Counties, there are a number of well-defined anticlinal structures that have been drilled upon with unsuccessful results. The Onondaga formation does not have a continuous bed of such porosity as would 
be needed for migration of oil, except within a restricted distance from its outcrop and from the Irvine fault. Therefore, migration of oil in this formation took place only over a short distance. As explained by the writer in a paper ${ }^{2}$ on the Irvine Oil District, the greater part of the porosity in certain beds of the Onondaga from which oil is produced is caused by solution by circulating meteoric water which has entered at the outcrop and along fault planes. It is this theory that explains the position and structural relations of the prolific Big Sinking Creek pool of Lee County.

In view of what has been said, Doctor Glenn's statement that water usually follows the oil in the Onondaga rather closely may need partial revision. It is true that wherever there is oil in commercial quantities there is also water, for water has in most cases caused the porosity in the rock in which the oil has accumulated. However, there are areas where there are very small wells of doubtful commercial value, the oil having accumulated in the Onondaga where there may have been a little porosity induced by recrystallization or partial dolomitization, where there is a total absence of water. Outside of a restricted distance from the outcrop of the Onondaga or from major faults, wells drilled on anticlines or in synclines show a general absence of both oil and water.

How far the thought developed by the writer, in his paper mentioned above, showing the relation between the area affected by circulation of meteoric water and oil accumulation in the Onondaga limestone in Kentucky can be applied to other fields where the oil production is from a porous limestone, cannot be stated, but he hoped that the idea advanced might be used with additions or modifications in helping to explain accumulation problems in other limestone fields.

Two minor corrections should be made in Doctor Glenn's paper for the benefit of those unfamiliar with the Kentucky fields. First, the gravity of the oil for the Irvine field is given correctly but it should not be thought to include the adjacent Big Sinking field. In the latter the gravity is much higher, running from $38^{\circ}$ to $42^{\circ}$ Bé. and the gasoline content is exceptionally high. Second, the great bulk of the oil in Kentucky is not earried by the Cumberland Pipe Line Co. at the present time. In the fields of Lee and adjacent counties, the Cumberland runs but little more than half the production; the balance is handled by six other pipe line companies, chief among which are the Indian Refining, Great Northern, and National Refining. In Allen County, the Indian Refining handles nearly all the production, although recently two other pipe lines have entered the field.

The writer fully agrees with Doctor Glenn in his outline of the areas of Jentucky that contain possibilities for future production. In his

${ }^{2}$ See p. 165. 
opinion, even the Allen, Barren, and Warren County areas are about outlined at the present time. In the western Kentucky coal field, development will be slow, but something of importance may be opened in the Chester or lower Mississippian sands. Kentucky cannot hope for a second Big Sinking, which is the most important feld in the history of oil production in the state. The flush was taken from this pool in 1919 and the production for that year will mark the apex of the production curve for the state. The decline in the curve will not be great for 1920 , but after this year the decline will be noticeable.

In Tennessee, aside from a probable few small pools along the Highland $\mathrm{Rim}$ in the limestone underlying the Chattanooga bJack shale and within a restricted distance from the outcrop of this limestone formation, or from a major fault, and a possible few small pools in the coal-measure area in the eastern part of the state, the oil possibilities, in the writer's opinion, lie in certain areas within the Gulf Embayment province west of Tennessee River. 